\title{
Parental age at mating affects reproductive attributes of the aphidophagous ladybird beetle, Coelophora saucia (Coleoptera: Coccinellidae)
}

\author{
OMKAR, SATYENDRA K. SINGH and GeETANJALi MISHRA
}

Ladybird Research Laboratory, Department of Zoology, University of Lucknow, Lucknow-226007, India; e-mail: omkaar55@hotmail.com

Key words. Coleoptera, Coccinellidae, Coelophora saucia, fecundity, egg viability, paternal age, maternal age

\begin{abstract}
Ageing and its affect on life attributes have not been widely explored in ladybirds. The present study investigates the influence of female and male age at mating on the reproductive attributes of the ladybird beetle, Coelophora saucia (Mulsant). All reproductive attributes, viz. fecundity, percentage egg hatch, pre-oviposition, oviposition and post-oviposition periods were found to be influenced by the ages of both females and males at mating. This is unlike the results of previous studies on ladybirds, where male age was found to influence only percentage egg hatch. The influence of male age at mating on fecundity and reproductive periods is probably due to age influenced variation in seminal proteins, which influence fecundity and when the eggs are laid.
\end{abstract}

\section{INTRODUCTION}

Senescence can be defined demographically as an agedependent increase in mortality risk, or functionally as a decline in performance (Medawar, 1952; Williams, 1957; Rose, 1991; Partridge \& Gems, 2002), and can be accounted for by several evolutionary and mechanistic theories (see Hughes \& Reynolds, 2005). The understanding of the ageing process is based on the relationship between the demographic and functional aspects, which are believed to be tightly linked, as ageing involves a decline in performance of several body functions, leading to increased mortality (Williams, 1999), and is observed in organisms ranging from flies (Grotewiel et al., 2005) to human beings (Burke \& Barnes, 2006).

This decline in physiological performance with age is known to be influenced by a number of factors prominent amongst which are dietary restrictions (Piper \& Partridge, 2007 and references therein) and reproduction (Rose, 1984; Finch, 1990, 1998; Tatar et al., 1993; Partridge et al., 1999; Finch \& Ruvkun, 2001; Robine, 2001). The acceleration of ageing in reproductively active individuals (Arnqvist \& Nilsson, 2000; Priest et al., 2002; Mishra \& Omkar, 2006), which is reflected in a deterioration in fitness and increase in mortality rate, is reported for a number of insects (Rose, 1984; Van Voorhies, 1992; Simmons \& Bradley, 1997; Mishra \& Omkar, 2006). The mechanism is explained in terms of reproductive costs (Partridge, 1986; Omkar \& Mishra, 2005) and trade offs (Kokko, 1998; Finch \& Ruvkun, 2001; Robine, 2001; Mishra \& Omkar, 2006).

Ageing is likely to affect mate choice and mortality patterns (Hansen \& Price, 1995; Kokko, 1998; Beck \& Powell, 2000; Kindlmann et al., 2001; Dixon \& Agarwala, 2002; Mishra \& Omkar, 2006). Although ageing has considerable implications for individual fitness, even in wild populations (Nesse, 1988; Bonduriansky \& Brassil, 2002), studies have typically relied on aggregate statistics from cohorts, while individual and sex specific variation in ageing rates remain poorly understood (Austad, 1996; Service et al., 1998; Partridge \& Mangel, 1999; Zens \& Peart, 2003; Mishra \& Omkar, 2006). Priest et al. (2002) recorded the role of sex-specific ageing on the fitness and survival patterns of future generations; maternal age and to a lesser extent paternal age were found to have a large influence on offspring longevity and their age-specific mortality. This aspect however needs further study.

As ageing is the outcome of inherent life-history trade offs and the condition of organisms, its effects can be recorded by changes in a number of aspects, such as fecundity, egg hatch and mortality, which have been exhaustively studied in many insects (Williams, 1957; Hamilton, 1966; Kirkwood, 1977; Partridge \& Barton, 1993). Recent studies on arthropods have investigated the effect of male or female age on mate choice (Hansen \& Price, 1995; Kokko, 1998; Beck \& Powell, 2000; Proulx et al., 2002), sperm quality and quantity (Hayashi, 1999; Green, 2003) sperm transfer rates (Jones et al., 2006), last male sperm precedence (LaMunyon, 2001; Schafer \& Uhl, 2002; Mack et al., 2003; Radwan et al., 2005), sperm competitive ability (Service \& Fales, 1993; Jones et al., 2006), musculature of genital tract (Mack et al., 2002) and sperm storage (Taylor et al., 2001). However, the very basic influence of age on life attributes is yet to be explored in detail in ladybirds, for which there are only a few studies (Dixon \& Agarwala, 2002; Pervez et al., 2004; Srivastava \& Omkar, 2004; Mishra \& Omkar, 2004, 2006; Omkar \& Singh, 2005; Omkar et al., 2006; Omkar \& Mishra, 2009). While most of these studies have concentrated on the effect of age on various reproductive parameters, the results are dependent on the species studied and require further study. The age at mating is an interesting aspect of age related studies in ladybirds.

Coelophora saucia (Mulsant), commonly called the Macular site ladybug and the Tokyo star in China, is an 
aphidophagous ladybird beetle, which is common in Northern India, China, Japan, Tawain, Thailand, Indonesia, Malaysia, Philippines, Vietnam and Korea (Hirano et al., 1996; Han, 1997; Berg et al., 1997; Omkar et al., 2005; Singh \& Tripathi, 2008). It is a relatively little studied ladybird, with only a few studies on its life attributes (Omkar \& Pathak, 2006, 2007; Omkar et al., 2005; Pathak, 2008) and none on the effect of parental age at mating. The present study investigates the effect of parental age at mating on reproductive attributes of $C$. saucia and increases the level of knowledge on this beetle and of ladybird physiology in general.

\section{MATERIAL AND METHODS}

\section{Stock culture}

Adults of $C$. saucia were collected from colonies of the aphid, Aphis craccivora Koch infesting bean (Dolichos lablab Linnaeus) in fields around Lucknow and brought to the laboratory $\left(25 \pm 2{ }^{\circ} \mathrm{C}, 60 \pm 5 \%\right.$ R.H and 14L: 10D). They were paired and reared in Petri dishes $(9.0 \times 2.0 \mathrm{~cm})$ on an ad libitum supply of prey (same species of aphid as above). Eggs were collected daily and the larvae reared to the pupal stage in glass beakers $(11.0 \times 9.0 \mathrm{~cm})$ in which the aphid prey was replenished daily. Beakers containing pupae were observed twice a day and newly emerged (NE) adults were sexed and isolated in Petri dishes and provided with an ad libitum supply of $A$. craccivora, which was replenished daily.

\section{Experimental setup}

\section{(A) Effect of female age}

Unmated adults of requisite ages were obtained from the stock culture. Virgin females aged 0 (newly emerged: NE), 1, 2, $4,6,8,10,20,30,40,50$ and 60 days were paired once with 10day-old males in plastic Petri dishes $(9.0 \times 2.0 \mathrm{~cm})$. Thereafter, the females were isolated and reared on a daily replenished ad libitum supply of $A$. craccivora for the remainder of their life. Number of eggs laid and subsequent percentage egg hatch were recorded daily. All observations were made once every $24 \mathrm{~h}$. There were 10 pairs in each mating group $(n=10)$.

\section{(B) Effect of male age}

Unmated adults of requisite ages were obtained from the stock culture. Virgin males aged 0 (newly emerged: NE), 1, 2, 4, $6,8,10,20,30,40,50$ and 60 days were paired once with 10 day-old females in plastic Petri dishes $(9.0 \times 2.0 \mathrm{~cm})$. Thereafter, the females were isolated and reared on a daily replenished ad libitum supply of $A$. craccivora for the remainder of their life. Number of eggs laid and percentage egg hatch were recorded once every $24 \mathrm{~h}$. As above there were 10 pairs in each mating group.

\section{Statistical analysis}

Data were checked for normality and found to be normally distributed. All percentages were arcsine square root transformed prior to statistical analysis. Data on pre-oviposition (time between mating and start of oviposition), oviposition (time spent egg laying) and post-oviposition (time between cessation of egg laying and death of females) periods, fecundity and percentage egg hatch were subjected to one-way ANOVA followed by post hoc Tukey's honest significance test using statistical software MINITAB (Minitab, 2000) with female or male age as the varying factor. Reproductive rate (fecundity/oviposition period) was also calculated and subjected to ANOVA. Data on NE to 4 day-old males, which did not mate, were not included in the analysis. Fecundity and percentage egg hatch were regressed against both female and male age in order to determine the relationships between these two parameters and age.

\section{RESULTS}

\section{(A) Effect of female age}

Females in all the age groups mated. Females of $C$. saucia that mated at the age of 20 days laid most eggs $(1979.6 \pm 197.9$; Mean \pm SE) and those mated when 60 days old the least $(240.0 \pm 16.3)$ (Table 1$)$. Fecundity differed significantly with the age at mating of females $(\mathrm{F}=$ 85.09; $\mathrm{P}<0.001$; d.f. $=11,119$; Table 1$)$ and showed a parabolic trend $\left(\mathrm{Y}=-35.053 \mathrm{X}^{2}+484.64 \mathrm{X}-419.65 ; \mathrm{r}^{2}=\right.$ 0.5815 ; Fig. 1) with a peak at female age of 20 days. Percentage egg hatch was also found to differ with age at mating of females, albeit less significantly $(\mathrm{F}=6.23 ; \mathrm{P}<$ 0.01 ; d.f. $=11,119$; Table 1$)$. It was highest for females

TABLE 1. Influence of female age at mating on the reproductive parameters of $C$. saucia.

\begin{tabular}{cccccccc}
\hline $\begin{array}{c}\text { Female age at } \\
\text { time of mating }\end{array}$ & $\begin{array}{c}\text { Fecundity } \\
\text { (no. of eggs) }\end{array}$ & $\begin{array}{c}\text { Percentage } \\
\text { egg hatch }\end{array}$ & $\begin{array}{c}\text { Pre-oviposition } \\
\text { period (in days) }\end{array}$ & $\begin{array}{c}\text { Oviposition } \\
\text { period (in days) }\end{array}$ & $\begin{array}{c}\text { Post oviposition } \\
\text { period (in days) }\end{array}$ & $\begin{array}{c}\text { Longevity } \\
\text { (in days) }\end{array}$ & $\begin{array}{c}\text { Reproductive } \\
\text { rate }\end{array}$ \\
\hline NE & $393.1 \pm 13.3 \mathrm{~b}$ & $71.9 \pm 2.5 \mathrm{a}$ & $6.5 \pm 0.6 \mathrm{e}$ & $27.8 \pm 0.9 \mathrm{c}$ & $27.2 \pm 2.1 \mathrm{f}$ & $54.0 \pm 4.6 \mathrm{~b}$ & $14.1 \pm 0.2 \mathrm{a}$ \\
1 & $447.6 \pm 23.0 \mathrm{c}$ & $80.7 \pm 1.2 \mathrm{~b}$ & $6.2 \pm 0.3 \mathrm{e}$ & $28.2 \pm 0.7 \mathrm{c}$ & $15.4 \pm 2.6 \mathrm{e}$ & $45.3 \pm 4.2 \mathrm{a}$ & $15.9 \pm 0.9 \mathrm{~b}$ \\
2 & $508.3 \pm 15.5 \mathrm{c}$ & $81.2 \pm 3.2 \mathrm{~b}$ & $5.3 \pm 0.4 \mathrm{~d}$ & $29.5 \pm 1.5 \mathrm{c}$ & $14.9 \pm 1.8 \mathrm{e}$ & $46.9 \pm 3.5 \mathrm{a}$ & $17.6 \pm 0.8 \mathrm{~b}$ \\
4 & $606.5 \pm 19.3 \mathrm{~d}$ & $83.4 \pm 1.8 \mathrm{~b}$ & $4.2 \pm 0.4 \mathrm{c}$ & $30.7 \pm 1.3 \mathrm{c}$ & $14.2 \pm 2.2 \mathrm{e}$ & $50.5 \pm 3.8 \mathrm{ab}$ & $19.9 \pm 0.5 \mathrm{~b}$ \\
6 & $647.2 \pm 34.3 \mathrm{~d}$ & $88.1 \pm 1.1$ & $3.9 \pm 0.2 \mathrm{c}$ & $35.3 \pm 1.7 \mathrm{~d}$ & $8.3 \pm 1.5 \mathrm{bc}$ & $51.1 \pm 3.9 \mathrm{ab}$ & $18.4 \pm 0.7 \mathrm{~b}$ \\
8 & $1121.1 \pm 82.1 \mathrm{f}$ & $89.6 \pm 1.2 \mathrm{c}$ & $2.9 \pm 0.3 \mathrm{bc}$ & $38.5 \pm 2.8 \mathrm{~d}$ & $9.3 \pm 2.5 \mathrm{c}$ & $51.3 \pm 4.1 \mathrm{ab}$ & $30.5 \pm 3.1 \mathrm{~d}$ \\
10 & $1506.4 \pm 150.6 \mathrm{~h}$ & $91.5 \pm 9.1 \mathrm{~cd}$ & $2.1 \pm 0.2 \mathrm{bc}$ & $49.4 \pm 4.9 \mathrm{e}$ & $5.9 \pm 0.6 \mathrm{a}$ & $63.4 \pm 6.3 \mathrm{c}$ & $27.9 \pm 2.8 \mathrm{c}$ \\
20 & $1979.6 \pm 197.9 \mathrm{i}$ & $93.2 \pm 9.3 \mathrm{~d}$ & $1.3 \pm 0.1 \mathrm{~b}$ & $56.0 \pm 5.6 \mathrm{e}$ & $7.8 \pm 0.8 \mathrm{~b}$ & $65.1 \pm 6.5 \mathrm{c}$ & $35.6 \pm 3.6 \mathrm{~d}$ \\
30 & $1219.7 \pm 102.9 \mathrm{~g}$ & $89.9 \pm 5.4 \mathrm{c}$ & $2.0 \pm 0.2 \mathrm{bc}$ & $36.9 \pm 2.3 \mathrm{~d}$ & $7.4 \pm 1.0 \mathrm{~b}$ & $65.5 \pm 0.9 \mathrm{c}$ & $33.9 \pm 3.6 \mathrm{~d}$ \\
40 & $853.8 \pm 46.2 \mathrm{e}$ & $82.7 \pm 3.8 \mathrm{~b}$ & $0.3 \pm 0.2 \mathrm{a}$ & $27.7 \pm 2.4 \mathrm{c}$ & $4.2 \pm 0.7 \mathrm{a}$ & $64.9 \pm 0.6 \mathrm{c}$ & $32.5 \pm 2.9 \mathrm{~d}$ \\
50 & $458.4 \pm 30.2 \mathrm{~b}$ & $76.7 \pm 4.3 \mathrm{a}$ & $0.0 \pm 0.0 \mathrm{a}$ & $20.4 \pm 2.3 \mathrm{~b}$ & $12.0 \pm 0.1 \mathrm{~d}$ & $73.1 \pm 0.4 \mathrm{~d}$ & $24.8 \pm 3.1 \mathrm{c}$ \\
60 & $240.0 \pm 16.3 \mathrm{a}$ & $72.7 \pm 3.5 \mathrm{a}$ & $0.0 \pm 0.0 \mathrm{a}$ & $12.7 \pm 1.4 \mathrm{a}$ & $6.7 \pm 0.5 \mathrm{~b}$ & $72.7 \pm 3.5 \mathrm{~d}$ & $20.8 \pm 2.7 \mathrm{~b}$ \\
F-value & $85.09^{* *}$ & $6.23 *$ & $60.08^{* *}$ & $43.55^{* *}$ & $13.22 * *$ & $10.87 * *$ & $12.00^{* *}$ \\
\hline
\end{tabular}

Values are Mean \pm S.E. $*$ and $* *$ indicate F-values significant at $\mathrm{P}<0.01$ and $\mathrm{P}<0.001$, respectively. Values in a column followed by different letters are significantly different. 
TABLE 2. Influence of male age at mating on the reproductive parameters of C. saucia.

\begin{tabular}{cccccccc}
\hline $\begin{array}{c}\text { Male age at } \\
\text { time of mating }\end{array}$ & $\begin{array}{c}\text { Fecundity } \\
\text { (no. of eggs) }\end{array}$ & $\begin{array}{c}\text { Percentage } \\
\text { egg hatch }\end{array}$ & $\begin{array}{c}\text { Pre-oviposition } \\
\text { period (in days) }\end{array}$ & $\begin{array}{c}\text { Oviposition } \\
\text { period (in days) }\end{array}$ & $\begin{array}{c}\text { Post-oviposition } \\
\text { period (in days) }\end{array}$ & $\begin{array}{c}\text { Longevity } \\
\text { (in days) }\end{array}$ & $\begin{array}{c}\text { Reproductive } \\
\text { rate }\end{array}$ \\
\hline NE & - & - & - & - & - & - & - \\
1 & - & - & - & - & - & - & - \\
2 & - & - & - & - & - & - & - \\
4 & - & - & - & - & - & - & - \\
6 & $433.6 \pm 43.4 \mathrm{a}$ & $84.4 \pm 8.4 \mathrm{a}$ & $4.3 \pm 0.4 \mathrm{c}$ & $20.7 \pm 2.1 \mathrm{a}$ & $17.3 \pm 1.7 \mathrm{~d}$ & $51.1 \pm 5.1 \mathrm{a}$ & $21.7 \pm 2.2 \mathrm{a}$ \\
8 & $673.0 \pm 67.3 \mathrm{~b}$ & $88.1 \pm 8.8 \mathrm{a}$ & $3.8 \pm 0.4$ & $31.0 \pm 3.1 \mathrm{~b}$ & $13.6 \pm 1.4 \mathrm{c}$ & $47.3 \pm 4.7 \mathrm{a}$ & $21.7 \pm 2.2 \mathrm{a}$ \\
10 & $1506.4 \pm 150.7 \mathrm{~d}$ & $91.5 \pm 9.2 \mathrm{ab}$ & $2.1 \pm 0.2 \mathrm{a}$ & $49.4 \pm 4.9 \mathrm{~d}$ & $5.9 \pm 0.6 \mathrm{~b}$ & $63.4 \pm 6.3 \mathrm{a}$ & $27.9 \pm 2.8 \mathrm{~b}$ \\
20 & $1653.3 \pm 165.3 \mathrm{~d}$ & $92.8 \pm 9.3 \mathrm{~b}$ & $2.8 \pm 0.3 \mathrm{ab}$ & $38.4 \pm 3.8 \mathrm{c}$ & $1.5 \pm 1.0 \mathrm{a}$ & $55.0 \pm 5.5 \mathrm{a}$ & $43.7 \pm 4.4 \mathrm{c}$ \\
30 & $1724.0 \pm 172.4 \mathrm{~d}$ & $94.7 \pm 9.5 \mathrm{~b}$ & $2.2 \pm 0.2 \mathrm{a}$ & $39.2 \pm 3.9 \mathrm{c}$ & $11.2 \pm 1.1 \mathrm{c}$ & $60.5 \pm 6.1 \mathrm{a}$ & $45.4 \pm 4.5 \mathrm{c}$ \\
40 & $904.0 \pm 90.4 \mathrm{c}$ & $90.3 \pm 9.0 \mathrm{ab}$ & $3.0 \pm 0.3 \mathrm{~b}$ & $32.9 \pm 3.3 \mathrm{~b}$ & $17.7 \pm 1.7 \mathrm{~d}$ & $63.7 \pm 6.4 \mathrm{a}$ & $27.9 \pm 2.8 \mathrm{~b}$ \\
50 & $696.5 \pm 69.6 \mathrm{~b}$ & $87.7 \pm 8.8 \mathrm{a}$ & $2.3 \pm 0.2 \mathrm{a}$ & $30.2 \pm 3.0 \mathrm{~b}$ & $17.4 \pm 1.7 \mathrm{~d}$ & $60.6 \pm 6.1 \mathrm{a}$ & $23.9 \pm 2.4 \mathrm{a}$ \\
60 & $534.3 \pm 53.4 \mathrm{a}$ & $81.4 \pm 8.1 \mathrm{a}$ & $3.2 \pm 0.3 \mathrm{ab}$ & $24.4 \pm 2.0 \mathrm{a}$ & $20.4 \pm 2.0 \mathrm{e}$ & $56.5 \pm 53.4 \mathrm{a}$ & $22.1 \pm 2.2 \mathrm{a}$ \\
F-value & $49.82^{* *}$ & $4.17 *$ & $7.27 * *$ & $35.73 * *$ & $7.01 * *$ & $7.11 * *$ & $13.84 * *$ \\
\hline
\end{tabular}

Values are Mean \pm S.E. $*$ and $* *$ indicate $\mathrm{F}$-values significant at $\mathrm{P}<0.01$ and $\mathrm{P}<0.001$, respectively. Values in a column followed by different letters are significantly different.

mated when 20 days old $(93.2 \pm 9.3 \%)$ and lowest for females mated at 60 days of age $(72.7 \pm 3.5 \%)(\mathrm{Y}=$ $-0.6211 \mathrm{X}^{2}+8.1866 \mathrm{X}+63.917 ; \mathrm{r}^{2}=0.9118$; Fig. 1). The reproductive periods, viz. pre-oviposition $(\mathrm{F}=60.08$; $\mathrm{P}<$ 0.001 ; d.f. $=11,119)$, oviposition $(\mathrm{F}=43.55 ; \mathrm{P}<0.001$; d.f. $=11,119)$ and post-oviposition $(\mathrm{F}=13.22 ; \mathrm{P}<0.001$; d.f. $=11,119)$ also differed significantly for the females mated at different ages. Pre-oviposition period decreased with increase in female age at mating up to 20 days and then increased, with a reverse trend in the oviposition period. Post-oviposition period on the other hand decreased with increase in female age at mating up to 40 days and then increased. The reproductive rate showed a parabolic relationship with female age at mating $(\mathrm{F}=$ 13.84; $\mathrm{P}<0.001$; d.f. $=11,119$; Table 1 ) with the peak at 20 days. Longevity increased with female age at mating. Thus, female age at mating significantly affected all the reproductive parameters, viz. pre-oviposition, oviposition and post-oviposition periods, fecundity and percentage egg hatch.

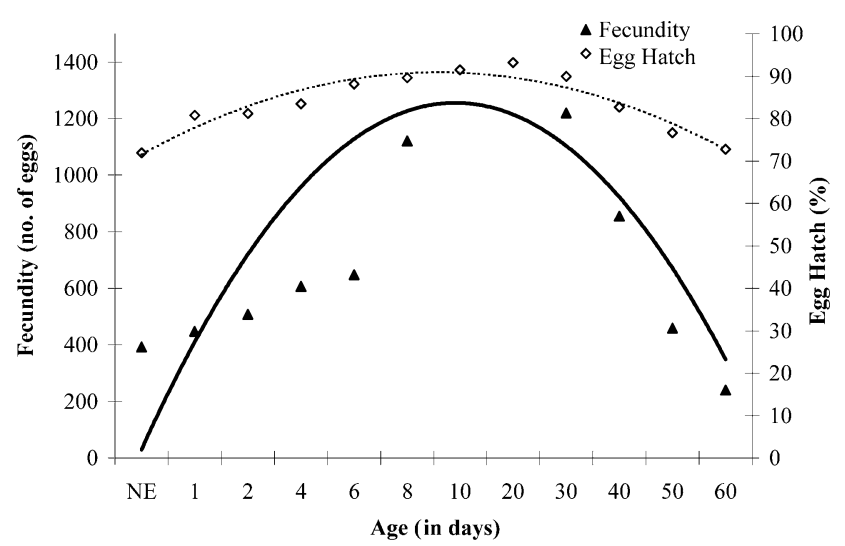

Fig. 1. The relationships between female age at mating, fecundity and egg hatch in C. saucia. Bold line indicates the trend in fecundity and the dashed line the trend in percentage egg hatch.

\section{(B) Effect of male age}

Recently emerged to 4 day old males did not mate and thus no reproductive parameters were recorded for them. In all the other treatments the males mated with females. The pre-oviposition period of female C. saucia mated with males of different ages differed significantly $(\mathrm{F}=$ 7.27; $\mathrm{P}<0.001$; d.f. $=7,79$; Table 2 ), as did the oviposition $(\mathrm{F}=35.73$; $\mathrm{P}<0.001$; d.f. $=7,79$; Table 2$)$ and postoviposition periods $(\mathrm{F}=7.11 ; \mathrm{P}<0.001$; d.f. $=7,79$; Table 2). Fecundity also differed significantly with male age at mating $(\mathrm{F}=49.82 ; \mathrm{P}<0.001 ;$ d.f. $=7,79$; Table 2$)$ with those females mated to males aged 30 days having the highest fecundity. However, there was no significant difference in the fecundity of females that were mated with 10-, 20- or 30-day old males. Fecundity in C. saucia increased with the age of the males that were mated with up to the age of 30 days, after which it declined ( $\mathrm{Y}=$ $-95.077 \mathrm{X} 2+844.81 \mathrm{X}-361.54 \mathrm{r}^{2}=0.7808$; Fig. 2). Percentage egg hatch was also influenced by paternal age at mating $(\mathrm{F}=4.17 ; \mathrm{P}<0.01$; d.f. $=7,79$; Table 2$)$ and was highest when males were 30 days old $\left(\mathrm{Y}=-0.8698 \mathrm{X}^{2}+\right.$

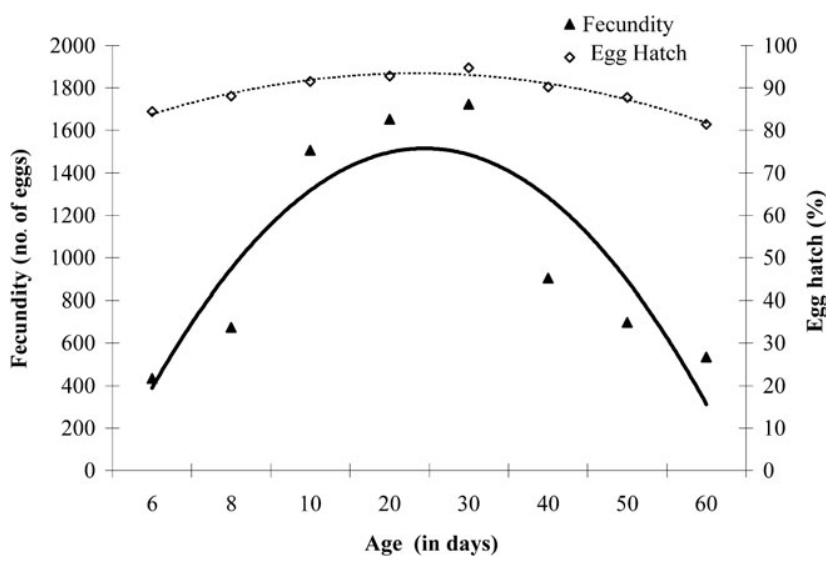

Fig. 2. The relationships between male age at mating, fecundity and egg hatch in C. saucia. Bold line indicates the trend in fecundity and the dashed line the trend in percentage egg hatch. 
7.5392X $+77.123 ; \mathrm{r}^{2}=0.964$; Fig. 2). The reproductive rate was also significantly dependent on male age at mating $(\mathrm{F}=13.84 ; \mathrm{P}<0.001$; d.f. $=7,79$; Table 2$)$. It was highest when the females were mated with 30 day old males, but not statistically different from when mated with 20 day old males.

\section{DISCUSSION}

The results reveal that the ages of both the female and male at mating affect reproductive performance in C. saucia. All reproductive parameters, viz. pre-oviposition, oviposition and post-oviposition periods, fecundity, percentage egg hatch and reproductive rate, were influenced by the ages of both the female and male at mating. An effect of the age of both sexes at mating on all reproductive parameters has not been reported before in ladybirds. Previous studies on ladybirds, viz. Propylea dissecta (Mulsant), Cheilomenes sexmaculata (Fabricius), and Coccinella septempunctata Linnaeus revealed the effect of male age is limited to percentage egg hatch and had no effect on fecundity and the length of the reproductive period (Pervez et al., 2004; Srivastava \& Omkar, 2004; Mishra \& Omkar, 2004; Omkar et al., 2006).

Fecundity in C. saucia was greatest when the females were first mated at the age of 20 days and for 10 day old females mated with 30 day old males. In another ladybeetle, Cryptolaemus montrouzieri Mulsant, 5-15 day old females laid the highest number of eggs (Jalali et al., 1999) and 20-day-old females of C. septempunctata and the pale morph of $P$. dissecta are the most fecund (Pervez et al., 2004; Srivastava \& Omkar, 2004). However, 30day-old females of the typical morph of $P$. dissecta are the most fecund (Mishra \& Omkar, 2004). Begon \& Parker (1986) previously suggested that egg or clutch size should change with maternal age, and this is recorded in a number of butterflies (Jones et al., 1982; Murphy et al., 1983; Wiklund \& Persson, 1983; Karlsson \& Wiklund, 1984, 1985). In ladybirds, the constraint on egg size (Dixon \& Guo, 1993) indicates that the variation in fecundity is a result of a change in clutch size. Since in ladybirds, the clutch size is half the number of ovarioles (Stewart et al., 1991) it is likely that the number of mature ovarioles decreases with age, which needs to be verified.

The decline in percentage egg hatch with maternal age indicates there are changes in the physiological state of the female genital tract, which might influence sperm transfer and motility. In Drosophila melanogaster mating with females older than 17 days, significantly reduced the precedence of the last male's sperm, indicating the outcome of sperm competition to be dependent on the physiological condition of the female genital tract (Mack et al., 2002). They suggest that the ability of the seminal receptacle to receive sperm from a new mating might be reduced because of functional senescence.

The decline in fecundity/egg hatch/reproductive output of older females might also be due to a preference for mating with older males. Genetic benefits of selecting partners are grouped into the two well recognized categories: "good genes" and "sexy sons" (Andersson, 1994).
The recently added third kind of benefit is the production of genetically fit offspring by selecting genetically compatible mates (Zeh \& Zeh, 1996, 1997, 2003; Tregenza \& Wedell, 2000), which is influenced by the accumulation of mutations and activation of late acting pleiotropic genes with increase in age (Partridge \& Barton, 1993; Pletcher \& Curstinger, 1998). It is thus likely that in the present study in which females of all ages were mated with young males (10 days old), the accumulation of mutations and activation of pleiotropic genes in older females might have reduced their fecundity. Also, the males might manipulate their ejaculate size in accordance with the age of females and so cause a decline in their reproductive output. Female age may also influence the probability of copulation or subsequent patterns of fertilization as is reported for the oblique-banded leaf roller Choristoneura rosaceana (Harris), where the former declines with age (Delisle, 1995) and possibly influences egg hatch.

The results also reveal that male age influenced all the reproductive parameters in $C$. saucia, not only egg hatch as in other ladybirds (Pervez et al., 2004; Srivastava \& Omkar, 2004; Mishra \& Omkar, 2004; Omkar et al., 2006). Such an influence on fecundity and reproductive period is recorded for species in which the males provide the females with nutrients during copulation (Fox, 1993a, b; Fox et al., 1995a; Savalli \& Fox, 1999a, b; Savalli et al., 2000). That this may occur in C. saucia is indicated by the increase in the longevity of females that mate many times compared with those that only mated once or a few times, as is recorded in another publication on this beetle (Omkar et al., 2010). Nutritional inputs provided by males are reported to take the form of (a) gifts of food (Arnqvist \& Nilsson, 2000) and/or (b) by varying the quantity and quality of the ejaculates (Arnqvist \& Nilsson, 2000). The former practice has not been observed in C. saucia, so the latter is likely to play a role in the change in reproductive parameters of females mated with males of different ages. A study by Fox et al. (1995b) on C. maculatus revealed a change in the quantity and quality of the ejaculate with age. Gillot (2003) reviewed the effect of male age on the quality and concentration of proteins in semen that are known to influence female fecundity and time of oviposition. Change in the frequency with which females mate along with male age might also determine the change in reproductive parameters (Fox et al., 1995b). A reduction in the quantity of sperm transferred with increase in male age may also account for the reduced fecundity of females.

The influence of paternal age on percentage egg hatch is reported for ladybirds (Pervez et al., 2004; Srivastava \& Omkar, 2004). This is most likely a consequence of age related changes in the physiological state of males.. This might manifest itself in four ways (a) sexual maturity of male (Pitnick et al., 1995; Baker et al., 2003), (b) change in quality or quantity of sperm with age (Hayashi, 1999; Taylor et al., 2001; Green, 2003), (c) change in the ability to transfer sperm (Jones et al., 2006), and/ or (d) change in sperm precedence and competitive ability 
(LaMunyon, 2001; Schafer \& Uhl, 2002; Mack et al., 2003; Radwan et al., 2005; Jones et al., 2006). In the hide beetle, Dermestes maculatus DeGeer, the probability of sperm transfer and the amount of sperm transferred vary with male age, but not with female age. Middle aged and old males are more likely to transfer sperm successfully and a greater quantity of sperm than young males. Sperm competitive ability varies with middle aged males achieving greater fertilization success when competing with young or old males (Jones et al., 2006).

The results of the present study may also indicate mate choice in C. saucia. Mate choice models for insects reveal that in certain cases young males have a selective advantage over older males (Hansen \& Price, 1995). The possible reason for this is their better genetic constitution (fewer mutations and lower pleiotropic activity of late acting genes; Partridge \& Barton, 1993; Pletcher \& Curstinger, 1998). The high reproductive output of the females mated with 10 to 30 -day-old males may indicate males in that age range are likely to be the preferred mates. This needs to be tested experimentally by age-based studies on mate choice in which the fitness consequences are recorded.

Thus, the present study reveals that both male and female age at mating altered the reproductive parameters, with the 20-day-old females mated with 10 to 30 -day-old males being the most productive.

ACKNOWLEDGEMENTS. The first two authors thank the Council of Science and Industrial Research, New Delhi for financial assistance in the form of a research grant.

\section{REFERENCES}

Andersson M. 1994: Sexual Selection. Princeton University Press, Princeton, $336 \mathrm{pp}$.

ARnQvist G. \& Nilsson T. 2000: The evolution of polyandry: multiple mating and female fitness in insects. Anim. Behav. 60: $145-164$.

AUSTAD S.N. 1996: The uses of intraspecific variation in aging research. Exp. Gerontol. 31: 453-463.

Baker R.H., Denniff M., Futerman P., Fowler K., PomianKOWSKi A. \& Chapman T. 2003: Accessory gland size influences time to sexual maturity and mating frequency in the stalk-eyed fly Cyrtodiopsis dalmanni. Behav. Ecol. 14: 607-611.

Beck C.W. \& Powell L.A. 2000: Evolution of female choice based on male age: Are older males better mates? Evol. Ecol. Res. 2: 107-118.

Begon M. \& Parker G.A. 1986: Should egg size and clutch size decrease with age? Oikos 47: 293-302.

Berg H., van den Ankasah D., Muhammad A., Rusli R., Widayanto H.A., Wirasto H.B. \& Yully I. 1997: Evaluating the role of predation in population fluctuations of the soybean aphid Aphis glycines in farmers' fields in Indonesia. J. Appl. Ecol. 34: 971-984.

Bonduriansky R. \& Brassil C.E. 2002: Rapid and costly ageing in wild male flies. Nature 420: 377.

Burke S.N. \& BARnes C.A. 2006: Neural plasticity in the ageing brain. Nat. Rev. Neurosci. 7: 30-40.

Deliste J. 1995: Effect of male and female age on the mating success of the oblique-banded leafroller Choristoneura rosaceana (Lepidoptera: Tortricidae) under different ecological conditions. J. Insect Behav. 8: 781-799.
Dixon A.F.G. \& Agarwala B.K. 2002: Triangular fecundity function and ageing in ladybird beetles. Ecol. Entomol. 27: 433-440.

Dixon A.F.G. \& Guo Y. 1993: Egg and cluster size in ladybird beetles (Coleoptera: Coccinellidae): The direct and indirect independence of aphid abundance. Eur. J. Entomol. 90: 457-463.

Finch C.E. 1990: Longevity Senescence and the Genome. University of Chicago Press, Chicago, $922 \mathrm{pp}$.

FinCH C.E. 1998: Variations in senescence and longevity include the possibility of negligible senescence. J. Gerontol. 53A: B235-B239.

Finch C.E. \& Ruvkun G. 2001: The genetics of aging. Annu. Rev. Genom. Hum. Genet. 2: 435-462.

Fox C.W. 1993a: Multiple mating lifetime fecundity and female mortality of the bruchid beetle Callosobruchus maculatus (Coleoptera: Bruchidae). Funct. Ecol. 7: 203-208.

Fox C.W. 1993b: The influence of maternal age and mating frequency on egg size and offspring performance in Callosobruchus maculatus (Coleoptera: Bruchidae). Oecologia 96: 139-146.

Fox C.W., McLennan A. \& Mousseau T.A. 1995a: Male body size affects female lifetime reproductive success in a seed beetle. Anim. Behav. 50: 281-284.

Fox C.W., Hickman D.L., Raleigh E.L. \& Mousseau T.A. 1995b: Paternal investment in a seed beetle (Coleoptera: Bruchidae): influence of male size, age, and mating history. Ann. Entomol. Soc. Am. 88: 101-103.

GiLlot C. 2003: Male accessory gland secretions: Modulators of female reproductive physiology and behavior. Annu. Rev. Entomol. 48: 163-184.

GREEN K. 2003: Age-related variation in mean sperm length in the rove beetle Aleochara bilineata. J. Insect Physiol. 49: 993-998.

Grotewiel M.S., Martin I., Bhandari P. \& Cook-Wiens E. 2005: Functional senescence in Drosophila melanogaster. Ageing Res. Rev. 4: 372-397.

HAMILTON W.D. 1966: The moulding of senescence by natural selection. J. Theor. Biol. 12: 12-45.

HaN X.C. 1997: Population dynamics of soybean aphid Aphis glycines and its natural enemies in fields. Hubei Agr. Sci. 2: 22-24.

Hansen T.F. \& Price D.K. 1995: Good genes and old genes. Do old mates provide superior genes? J. Evol. Biol. 8: 759-778.

HAYASHI F. 1999: Ejaculate production schedule and the degree of protandry in fishflies (Megaloptera: Corydalidae). Funct. Ecol. 13: 178-189.

Hirano H., Honda K.I. \& Miyai S. 1996: Effects of temperature on development longevity and reproduction of the soybean aphid Aphis glycines (Homoptera: Aphididae). Appl. Entomol. Zool. 311: 178-180.

Hughes K.A. \& Reynolds R.M. 2005: Evolutionary and mechanistic theories of aging. Annu. Rev. Entomol. 50: 421-445.

JaLaLi SK., Singh S.P. \& Biswas S.R. 1999: Effect of temperature and female age on the development and progeny production of Cryptolaemus montrouzieri Mulsant (Coleoptera: Coccinellidae). Entomon 24: 293-296.

Jones R.E., Hart J.R. \& Bull G.D. 1982: Temperature, size and egg production in the cabbage butterfly Pieris rapae L. Aust. J. Zool. 30: 223-232.

Jones T.M., Featherston R., Damien Paris B.B.P. \& Elgar M.A. 2006: Age-related sperm transfer and sperm competitive ability in the male hide beetle. Behav. Ecol. 18: 251-258.

KarlsSON B. \& WiKLUND C. 1984: Egg weight variation and lack of correlation between egg weight and offspring fitness 
in the wall brown butterfly, Lassiommata megera. Oikos $\mathbf{4 3}$ : $367-385$.

KARLSSON B. \& WiKLund C. 1985: Egg weight variation in relation to egg mortality and starvation endurance of newly hatched larvae in some satyrid butterflies. Ecol. Entomol. 10: 205-211.

Kindlmann P., Dixon A.F.G. \& Dostalkova I. 2001: Role of ageing and temperature in shaping reaction norms and fecundity functions in insects. J. Evol. Biol. 14: 835-840.

KIRKwood T.B.L. 1977: Evolution of ageing. Nature 270: 301-304.

Kокко H. 1998: Good genes, old age and life-history trade-offs. Evol. Ecol. 12: 739-750.

LAMunYon C.W. 2001: Determinants of sperm precedence in a noctuid moth Heliothis virescens: a role for male age. Ecol. Entomol. 26: 388-394.

Mack P.D., Наммоск B.A. \& Promislow D.E.L. 2002: Sperm competitive ability and genetic relatedness in Drosophila melanogaster: similarity breeds contempt. Evolution 56: $1789-1795$.

Mack P.D., Priest N.K. \& Promislow D.E.L. 2003: Female age and sperm competition: last-male precedence declines as female age increases. Proc. R. Soc. Lond. (B) (Biol. Sci.) 270: $159-165$.

Medawar P.B. 1952: An Unsolved Problem of Biology. H.K. Lewis, London.

Minitab-13.1 2003: Minitab Inc. State College Pennsylvania USA

Mishra G. \& OMKaR 2004: Influence of parental age on reproductive performance of an aphidophagous ladybird Propylea dissecta (Mulsant). J. Appl. Entomol. 128: 605-609.

Mishra G. \& OMKAR 2006: Ageing trajectory and longevity trade-off in a generalist aphidophagous ladybird, Propylea dissecta (Coleoptera: Coccinellidae). Eur. J. Entomol. 103: $33-40$.

Murphy P.A., Giesel J.T. \& Manlove M.N. 1983: Temperature effects on life history variation in Drosophila simulans. Evolution 37: 1181-1192.

NeSSE R.M. 1988: Life table tests of evolutionary theories of senescence. Exp. Gerontol. 23: 445-453.

OMKAR \& Mishra G. 2005: Mating in aphidophagous ladybirds: costs and benefits. J. Appl. Entomol. 129: 432-436.

OMKAR \& Mishra G. 2009: Optimization of age differences between mates maximizes reproductive output. BioControl 54: 637-650.

OMKAR \& PATHAK S. 2006: Effects of different photoperiods and wavelengths of light on life-history traits of an aphidophagous ladybird Coelophora saucia (Mulsant). J. Appl. Entomol. 130: 45-50.

Omkar \& Pathak S. 2007: Sexual dimorphism in an aphidophagous ladybird beetle Coelophora saucia. J. Appl. Biosci. 332: $180-181$.

OMKAR \& SingH S.K. 2005: Influence of maternal age on reproductive performance of two aphidophagous ladybirds. J. Appl. Biosci. 31: 43-48.

Omkar, Pervez A. \& Singh S.K. 2005: Development and immature survival of two aphidophagous ladybirds Coelophora biplagiata and Micraspis discolor. Insect Sci. 12: 375-379.

OMKAR, SinGH S.K. \& SiNGH K. 2006: Effect of age on reproductive attributes of an aphidophagous ladybird Cheilomenes sexmaculata. Insect Sci. 13: 301-308.

OMKar, Singh S.K. \& Mishra G. 2010: Multiple matings affect the reproductive performance of an aphidophagous ladybird beetle, Coelophora saucia. Eur. J. Entomol. 107: 177-182.
Partridge L. 1986: Sexual activity and life span. In Collatz K.G. \& Sohal R.S. (eds): Insect Aging Strategies and Mechanisms. Springer, Berlin, pp. 45-54.

Partridge L. \& Barton N.H. 1993: Optimality mutation and the evolution of ageing. Nature 362: 305-311.

Partridge L. \& Gems D. 2002: Mechanisms of aging: public or private? Nat. Rev. Genet. 3: 165-175.

Partridge L. \& Mangel M. 1999: Messages from mortality: the evolution of death rates in the old. Trends Ecol. Evol. 14: 438-442.

Partridge L., Prowse N. \& Pignatelli P. 1999: Another set of responses and correlated responses to selection on age at reproduction in Drosophila melanogaster. Proc. R. Soc. Lond. 266: 255-261.

Pатнак S. 2008: Life Attributes of an Aphidophagous Ladybird, Coelophora saucia (Mulsant). Thesis, University of Lucknow, 223 pp.

Pervez A., Omkar \& Richmond A.S. 2004: The influence of age on reproductive performance of a predatory ladybird beetle Propylea dissecta. J. Insect Sci. 4: 22: 1-8.

Piper M. \& PARTRIDGe L. 2007: Dietary restriction in Drosophila: delayed aging or experimental artifact? Plos Genet. 3(4): e57.

Pitnick S., Markow T.A. \& Spicer G.S. 1995: Delayed male maturity is a cost of producing large sperm in Drosophila. Proc. Natl. Acad. Sci. USA 92: 10614-10618.

Pletcher S.D. \& Curtsinger J.W. 1998: Mortality plateaus and the evolution of senescence: why are old-age mortality rates so low? Evolution 52: 454-464.

Priest N.K., Mackowiak B. \& Promislow D.E.L. 2002: The role of parental age effects on the evolution of aging. Evolution 56: 927-935.

ProulX S.R., Day T. \& Rowe L. 2002: Older males signal more reliably. Proc. R. Soc. Lond. (B) Biol. Sci. 269: 2291-2299.

Radwan J., Michalczyk L. \& Prokop Z. 2005: Age dependence of male mating ability and sperm competition success in the bulb mite. Anim. Behav. 69: 1101-1105.

RoBINE J.M. 2001: A new biodemographic model to explain the trajectory of mortality. Exp. Gerontol. 36: 899-914.

Rose A.R. 1984: Laboratory evolution of postponed senescence in Drosophila melanogaster. Evolution 38: 1004-1010.

Rose M. 1991: Evolutionary Biology of Aging. Oxford University Press, New York, 221 pp.

Savalli U.M. \& Fox C.W. 1999a: The effect of male size, age, and mating behavior on sexual selection in the seed beetle Callosobruchus maculatus. Ethol. Ecol. Evol. 10: 49-60.

Savalli U.M. \& Fox C.W. 1999b: The effect of male mating history on paternal investment fecundity and female remating in the seed beetle Callosobruchus maculatus. Funct. Ecol. 13: 169-177.

Savalli U.M., Czesak M.E. \& Fox C.W. 2000: Paternal investment in the seed beetle Callosobruchus maculatus (Coleoptera: Bruchidae): Variation among populations. Ann. Entomol. Soc. Am. 93: 1173-1178.

Schafer M.A. \& Uhl G. 2002: Determinants of paternity success in the spider Pholcus phalangioides (Pholcidae: Araneae): the role of male and female mating behaviour. Behav. Ecol. Sociobiol. 51: 368-377.

Service P.M. \& Fales A.J. 1993: Evolution of delayed reproductive senescence in male fruit-flies: sperm competition. Genetica 91: 111-125.

Service P.M., Michieli C.A. \& McGill K. 1998: Experimental evolution of senescence: an analysis using a "heterogeneity" mortality model. Evolution 52: 1844-1850. 
Simmons F.H. \& Bradley T.J. 1997: An analysis of resource allocation in response to dietary yeast in Drosophila melanogaster. J. Insect Physiol. 43: 779-788.

SinGH S.K. \& TRIPATHI G.M. 2008: Record of sugarcane woolly aphid Ceratovacuna lanigera Zehntner (Homoptera: Aphididae) and its natural enemies in Uttar Pradesh and Uttaranchal. Resist. Pest Manag. Newslett. 18: 40-41.

SRIVASTaVa S. \& OMKar 2004: Age specific mating and reproductive senescence in seven spotted ladybird Coccinella septempunctata. J. Appl. Entomol. 128: 452-458.

Stewart L.A., Hemptinne J.L. \& Dixon A.F.G. 1991: Reproductive tactics of ladybird beetles: relationship between egg size, ovariole number and development time. Funct. Ecol. 5: 380-385.

Tatar M., Carey J.R. \& VAuPEL J.W. 1993: Long-term cost of reproduction with and without accelerated senescence in Callosobruchus maculatus: analysis of age-specific mortality. Evolution 47: 1302-1312.

Taylor P.W., Kaspi R., Mossinson S. \& Yuval B. 2001: Agedependent insemination success of sterile Mediterranean fruit flies. Entomol. Exp. Appl. 98: 27-33.

Tregenza T. \& Wedell N. 2000: Genetic compatibility mate choice and patterns of parentage: invited review. Mol. Ecol. 9: 1013-1027.
VAN VOORHIES W.A. 1992: Production of sperm reduces nematode lifespan. Nature 360: 456-458.

Wiklund C. \& Persson A. 1983: Fecundity and the relation of egg weight variation to offspring fitness in the speckle wood butterfly Pararge aegeria or why don't female butterflies lay more eggs? Oikos 40: 53-63.

WiLliams G.C. 1957: Pleiotropy natural selection and the evolution of senescence. Evolution 11: 398-411.

WiLliams G.C. 1999: The Tithonus error in modern gerontology. Q. Rev. Biol. 74: 405-415.

Zен J.A. \& Zен D.W. 1996: The evolution of polyandry I. Intragenomic conflict and genetic incompatibility. Proc. R. Soc. Lond. (B) 263: 1711-1717.

Zен J.A. \& Zeн D.W. 1997: The evolution of polyandry II. Postcopulatory defences against genetic incompatibility. Proc. $R$. Soc. Lond. (B) 264: 69-75.

Zен J.A. \& Zен D.W. 2003: Toward a new sexual selection paradigm: polyandry conflict and incompatibility. Ethology 109: 929-950.

Zens M.S. \& Peart D.R. 2003: Dealing with death data: individual hazards mortality and bias. Trends Ecol. Evol. 18: 366-373.

Received October 26, 2009; revised and accepted March 3, 2010 